\section{Correspondence}

https://doi.org/10.11646/zootaxa.5100.1.9

http://zoobank.org/urn:lsid:zoobank.org:pub:55F4FF48-1927-45E4-AD97-DDC7D83FE8C2

\title{
The advertisement and courtship calls of Phyllobates bicolor (Anura: Dendrobatidae) from a natural population in the Colombian pacific cloud forests
}

\author{
MARCO GONZÁLEZ-SANTORO ${ }^{1 *}$, PABLO PALACIOS-RODRÍGUEZ ${ }^{1,3}$, JACK HERNÁNDEZ-RESTREPO ${ }^{1,4}$, \\ DANIEL MEJÍA-VARGAS² \& ADOLFO AMÉZQUITA ${ }^{1,5}$ \\ ${ }^{1}$ Department of Biological Sciences, Universidad de los Andes, Bogotá AA 4976, Colombia. \\ ${ }^{2}$ Independent researcher. ㄴ https://orcid.org/0000-0002-9547-9688 \\ ${ }^{3}$ ○ https://orcid.org/0000-0001-5626-5540 \\ 4 ๑ https://orcid.org/0000-0002-7676-7027 \\ 5 ๑ https://orcid.org/0000-0001-7320-1143 \\ ${ }^{*}$ Corresponding author. =" md.gonzalez10@gmail.com; @ https://orcid.org/0000-0002-3116-525X
}

Phyllobates bicolor (Bibron in La Sagra, 1840) is the type species of the genus Phyllobates, which includes four other species (sensu Grant et al., 2017): P. vittatus (Cope, 1893), P. lugubris (Schmidt, 1857), P. aurotaenia (Boulenger, 1913) and P. terribilis (Myers et al., 1978). Intense populations reduction and fragmentation (Kahn et al., 2016) coupled to the occurrence of taxonomic misidentifications since its description (Silverstone, 1976; Myers et al., 1978; Maxson \& Myers, 1985; Lötters et al., 1997; Widmer et al., 2000; Márquez et al., 2012) have constrained the study of the acoustic communication in P. bicolor. Zimmermann \& Zimmermann (1985) described P. bicolor's advertisement and courtship calls in captivity, presumably misidentified as P. terribilis (Lötters et al., 2007; Kahn et al., 2016). Even so, calling behaviour in frogs in natural conditions may not be mirrored in captivity (Köhler et al., 2017). On the other hand, Erdtmann \& Amézquita (2009) summarized the advertisement call of $P$. bicolor using the data of only one individual whose origin is not stated and retrieved from a public database which is currently not accessible. Recently, we visited two populations in Santa Cecilia (Risaralda, Colombia) that match the phenotypic description (Myers et al., 1978; Kahn et al., 2016) and the geographic distribution (Myers \& Böhme, 1996; Márquez et al., 2020) of P. bicolor. This study aimed to describe the advertisement (AC) and courtship calls (CC) of P. bicolor in natural conditions.

We recorded the AC of six individuals of $P$. bicolor in July 2018, in a secondary forest during early hours in the morning (6-9 am). For each individual, we recorded $\sim 1$ min of consecutive and spontaneous advertisement calls with a Zoom H4n pro digital recorder coupled to a directional (Sennheiser ME66/K6P) microphone placed about $2 \mathrm{~m}$ in front of the calling male. The $\mathrm{CC}$ was recorded for only one individual as the occurrence of both male and female is not common. Immediately after recording, we measured the temperature of the frog back using an infrared thermometer (Oakton model WD-35639) and captured the frog to measure its body size (snout-vent-length, SVL) to the nearest $0.01 \mathrm{~mm}$ with a digital calliper (Table 1).

We used the software Raven Pro 1.3 to measure four temporal (note duration, note interval, call duration and number of notes) and three spectral (note dominant frequency, note minimum frequency and note maximum frequency) features of the $\mathrm{AC}$, and three temporal (call duration, pulse number and pulse duration) and six spectral (call and pulse dominant frequency, call and pulse minimum frequency, and call and pulse maximum frequency) features of the CC, based on Köhler et al. (2017). The recordings were analysed using a sampling rate of $44.1 \mathrm{kHz}$ with an FFT of 512 points, allowing $50 \%$ of overlap between points, using the Blackman window type. Using identical parameters, the R package Seewave (Sueur et al., 2008) was used to create the spectrograms and sonograms (Fig. 1). Sound recordings were deposited at the Colección de Sonidos Ambientales of the Instituto Alexander von Humboldt, Colombia (IAvH-CSA-34251 to IAvHCSA-34257) and at the Macaulay library at the Cornell Laboratory of Ornithology. We reported measurements as mean \pm standard deviation (range).

Considering Köhler et al. (2017) classification, the AC of $P$. bicolor is best described as a call composed by a series of notes, in which each note is produced by a single expiration (Fig 1A, B, C). Each call has a duration of $6.6 \pm 1 \mathrm{~s}$, composed by a series of $75.4 \pm 6.9$ notes. The latter, in turn, are best described as unpulsed, tonal with frequency modulation (Fig 1C). Each note has an average duration of $37.3 \pm 2 \mathrm{~ms}$ which is similar to Erdtmann \& Amézquita (2009) values 
(38 ms) but with only some of the recordings of Zimmermann \& Zimmermann (1985) (62.9 $\pm 22.6 \mathrm{~ms})$. We argue that the greater variation and higher values in the latter description done in captivity, in comparison to our data, are probably due to reverberation effects, common in enclosures. On the other hand, the AC notes' frequency values of our study are accordant with previous reports (Table 1).

The courtship call of $P$. bicolor is best described as a single pulsatile harmonic note (Fig 1E). Given that it is emitted only in the presence of a female it has been described as a short-range call (Zimmermann, 1989). It is characterized by lower frequency and longer duration values in comparison to the notes of the AC (comparison performed only within the individual that issued the courtship call, CC: $2670 \mathrm{~Hz}$ and $242.8 \pm 4.9 \mathrm{~ms}, \mathrm{AC}: 2954 \pm 22 \mathrm{~Hz}$ and $34.7 \pm 1.6 \mathrm{~ms}$ ). Zimmermann \& Zimmermann (1985) described longer CC than ours (606 $\pm 243 \mathrm{~ms}$ ), probably due to reverberation effects as it happened for the AC (Table 2). We observed that the CC varied within the temporal domain (Fig 1E), therefore, we analysed the call taking measurements of the whole call but also at the initial, middle, and final parts of the signal (Table 2). Overall, this work expands our knowledge of Colombian endangered poison frogs and highlights the importance to study acoustic communication in natural conditions.
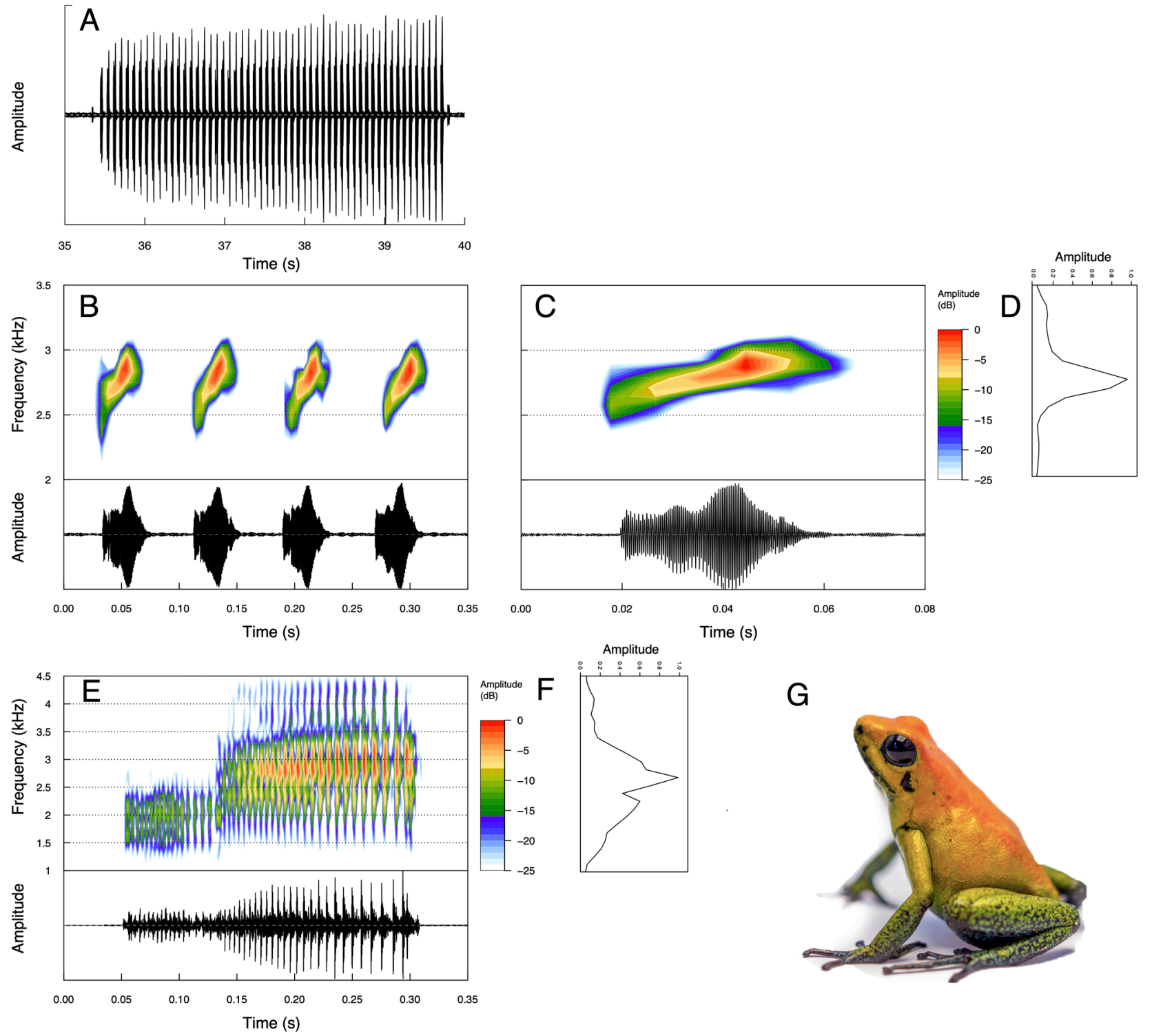

FIGURE 1. Advertisement call: sonogram of a series of notes (A), spectrogram and sonogram of four consecutive notes (B), spectrogram and sonogram of a single note (C), and the spectrum of power (D). Courtship call: spectrogram and sonogram of the whole signal (E), and spectrum of power (F). Individual of P. bicolor, photo taken by JHR (G). 


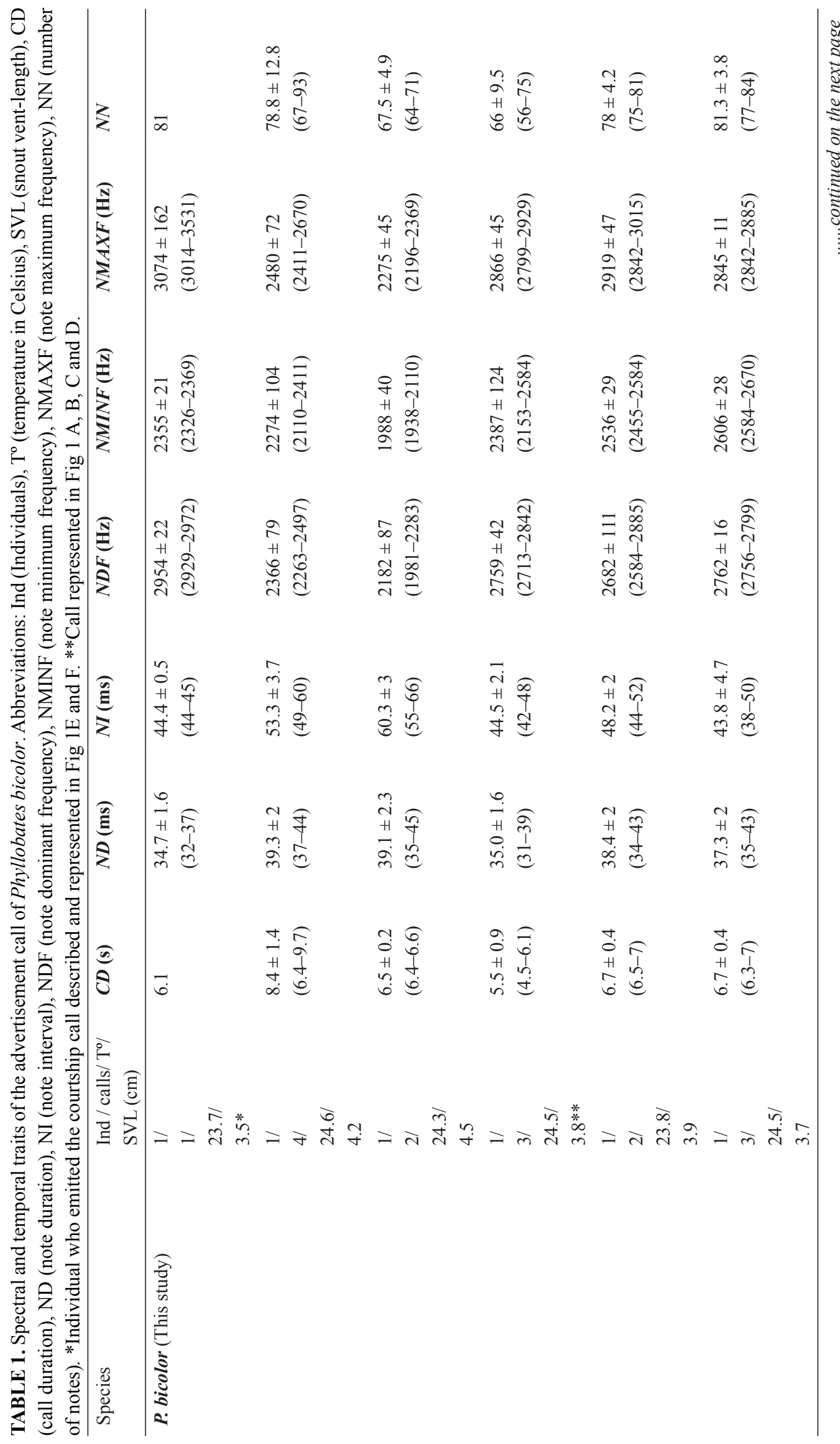




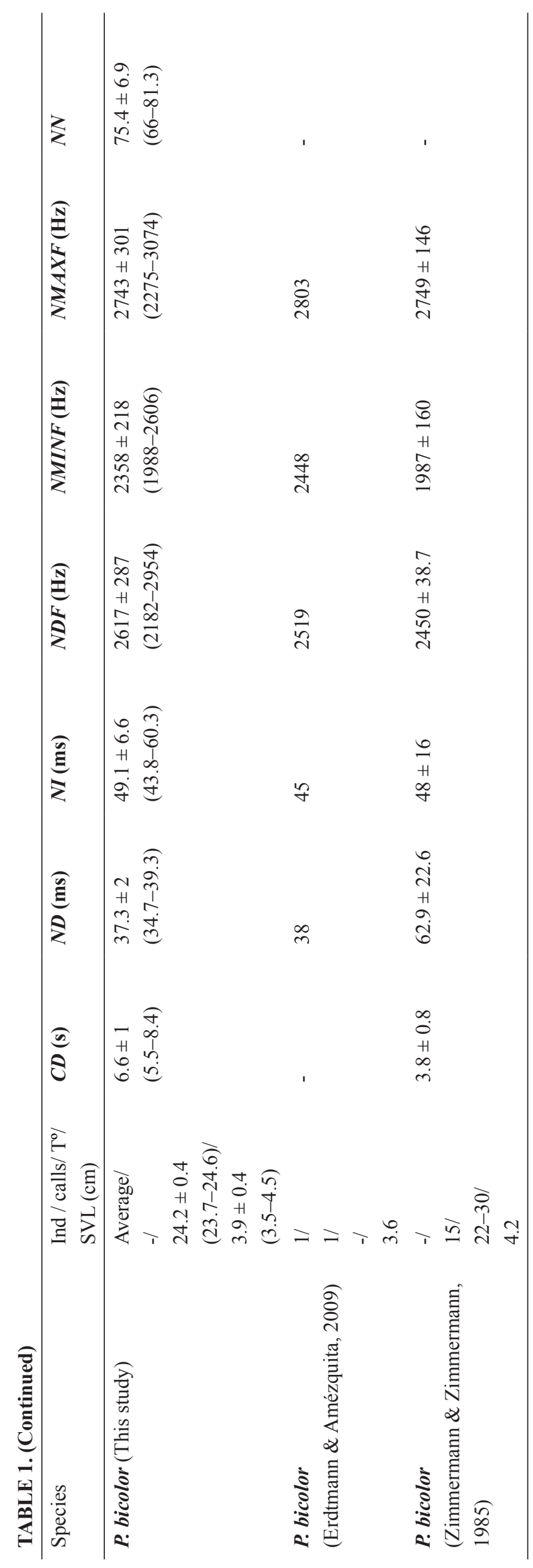

148 • Zootaxa 5100 (1) (C) 2022 Magnolia Press 
TABLE 2. Spectral and temporal traits of the courtship call of Phyllobates bicolor. Abbreviations: Ind (Individuals), CD (call duration), CDF (call dominant frequency), CMINF (call minimum frequency), CMAXF (call maximum frequency), PN (pulse number), PD (pulse duration), PDF (pulse dominant frequency), PMINF (pulse minimum frequency), and PMAXF (pulse maximum frequency).

\begin{tabular}{lllllll}
\hline Species & Ind /calls & $\boldsymbol{C D}(\mathbf{m s})$ & $\boldsymbol{C D F}(\mathbf{H z})$ & $\boldsymbol{C M I N F}(\mathbf{H z})$ & $\boldsymbol{C M A X F}(\mathbf{H z})$ & $\boldsymbol{P N}$ \\
\hline $\boldsymbol{P}$. bicolor & $1 / 2$ & $242.8 \pm 4.9$ & $2670 \pm 0$ & $1852 \pm 61$ & $3187 \pm 0$ & $46 \pm 0.7$ \\
(This study) & & $(239.3-246.3)$ & & $(1809-1895)$ & & $(45-46)$ \\
$\begin{array}{l}\boldsymbol{P} \text { bicolor } \\
\text { (Zimmermann \& }\end{array}$ & $-/ 12$ & $606 \pm 243$ & $2375 \pm 84$ & $1739 \pm 162$ & $2875 \pm 296$ & - \\
Zimmermann, 1985) & & & & & & \\
\hline
\end{tabular}

\section{TABLE 2. (Continued)}

\begin{tabular}{llllll}
\hline Species & Call Section & $\boldsymbol{P D}(\mathbf{m s})$ & $\boldsymbol{P D F}(\mathbf{H z})$ & $\boldsymbol{P M I N F}(\mathbf{H z})$ & $\boldsymbol{P M A X F ( H z )}$ \\
\hline $\boldsymbol{P}$. bicolor & Initial & $4.2 \pm 0.8$ & $1947 \pm 83$ & $1370 \pm 27$ & $2248 \pm 75$ \\
(This study) & & $(3.5-6.4)$ & $(1809-2067)$ & $(1292-1378)$ & $(2153-2412)$ \\
& Middle & $5.8 \pm 1.3$ & $2607 \pm 181$ & $2059 \pm 72$ & $3132 \pm 111$ \\
& & $(4.6-8.5)$ & $(2239-2842)$ & $(1895-2153)$ & $(3015-3359)$ \\
& Final & $10.3 \pm 2.4$ & $2708 \pm 63$ & $2125 \pm 61$ & $3283 \pm 100$ \\
& & $(7.5-14.8)$ & $(2670-2842)$ & $(2067-2239)$ & $(3187-3445)$ \\
\hline
\end{tabular}

\section{Acknowledgements}

We thank "Blas" for his help in the field work, Ana M. Ospina for her help on acoustic data analysis and graphical representation, and the OTS for a scholarship granted to MGS to assist to the Bioacoustics Analysis in R course.

\section{References}

Erdtmann, L. \& Amézquita, A. (2009) Differential evolution of advertisement call traits in Dart-Poison Frogs (Anura: Dendrobatidae). Ethology, 115 (9), 801-811. https://doi.org/10.1111/j.1439-0310.2009.01673.x

Grant, T., Rada, M., Anganoy-Criollo, M., Batista, A., Dias, P.H., Jeckel, A.M., Machado, D.J. \& Rueda-Almonacid, J.V. (2017) Phylogenetic systematics of dart-poison frogs and their relatives revisited (Anura: Dendrobatoidea). South American Journal of Herpetology, 12, 1-90. https://doi.org/10.2994/SAJH-D-17-00017.1

Kahn, T.R., La Marca, E., Lötters, S., Brown, J.L., Twomey, E. \& Amézquita, A. (2016) Aposematic Poison Frogs (Dendrobatidae) of the Andean Countries: Bolivia, Colombia, Ecuador, Per and Venezuela. Conservation International Tropical Field Guide Series, Conservation International, Arlington, Virginia, 588 pp.

Köhler, J., Jansen, M., Rodríguez, A., Kok, P.J.R., Toledo, L.F., Emmrich, M., Glaw, F., Haddad, C.F.B., Rödel, M.O. \& Vences, M. (2017) The use of bioacoustics in anuran taxonomy: theory, terminology, methods and recommendations for best practice. Zootaxa, 4251 (1), 001-124. https://doi.org/10.11646/zootaxa.4251.1.1

Lötters, S., Castro Herrera, F., Köhler, J. \& Richter, R. (1997) Notes on the distribution and color variation of poison frogs of the genus Phyllobates from western Colombia (Anura: Dendrobatidae). Revue française d'aquariologie, 24 (1-2), 55-58.

Lötters, S., Jungfer, K.H., Schmidt, W. \& Henkel, F.W. (2007) Poison Frogs: Biology, Species and Captive Husbandry. Edition Chimaira. Frankfurt am Main, 668 pp.

Márquez, R., Corredor, G., Galvis, C., Góez, D. \& Amézquita, A. (2012) Range extension of the critically endangered true poison-dart frog, Phyllobates terribilis (Anura: Dendrobatidae), in western Colombia. Acta Herpetologica, 7 (2), $341-345$.

Márquez, R., Linderoth, T.P., Mejía-Vargas, D., Nielsen, R., Amézquita, A. \& Kronforst, M.R. (2020) Divergence, gene flow, and the origin of leapfrog geographic distributions: The history of colour pattern variation in Phyllobates poison-dart frogs. Molecular Ecology, 29 (19), 3702-3719. https://doi.org/10.1111/mec.15598

Maxson, L.R. \& Myers, C.W. (1985) Albumin evolution in tropical poison frogs (Dendrobatidae): a preliminary report. Biotropica, 17 (1), 50-56. https://doi.org/10.2307/2388378 
Myers, C.W., Daly, J.W. \& Malkin, B. (1978) A dangerously toxic new frog (Phyllobates) used by Emberá indians of western Colombia, with discussion of blowgun fabrication and dart poisoning. Bulletin of the American Museum of natural History, 161, 307-366.

Myers, C.W. \& Böhme, W. (1996) On the type specimens of two Colombian poison frogs described by AA Berthold (1845), and their bearing on the locality" Provinz Popayan". American Museum Novitates, 3185, 1-20.

Silverstone, P. (1976) A revision of the poison arrow frogs of the genus Phyllobates Bibron in Sagra (family Dendrobatidae). Natural History Museum of Los Angeles County, 27, 1-53.

Sueur, J., Aubin, T. \& Simonis, C. (2008) Seewave, a free modular tool for sound analysis and synthesis. Bioacoustics, 18 (2), 213-226. https://doi.org/10.1080/09524622.2008.9753600

Widmer, A., Lötters, S. \& Jungfer, K.H. (2000) A molecular phylogenetic analysis of the neotropical dart-poison frog genus Phyllobates (Amphibia: Dendrobatidae). Die Naturwissenschaften, 87 (12), 559-562. https://doi.org/10.1007/s001140050779

Zimmermann, H. \& Zimmermann, E. (1985) Zur Fortpflanzungsstrategie des Pfeilgiftfrosches Phyllobates terribilis Myers, Daly \& Malkin, 1978. Salamandra, 21 (4), 281-297.

Zimmermann, H. (1989) Conservation studies on the 'dart-poison' frogs Dendrobatidae in the field and in captivity. International Zoo Yearbook, 28 (1), 31-44.

https://doi.org/10.1111/j.1748-1090.1989.tb03250.x 